\title{
Çok Kademeli Buhar Sıkıştırmalı İdeal Soğutma Çevrimlerinde Farklı Soğutucu Akışkanlar Kullanarak Enerji ve Ekserji Analizi
}

\author{
Energetic And Exergetic Analysis of a Multistage Vapor \\ Compression Refrigeration System With Various Refrigerants
}

Geliş / Received: 17/11/2020

Alaattin Metin Kaya ${ }^{1 *}$

Revize / Revised: 01/02/2021

Kabul / Accepted: 03/02/2021

\section{ÖZ}

Çok kademeli buhar sıkıştırmalı soğutma çevrimleri, düşük sıcaklık uygulamalarında kullanılmasının yanı sıra, sıcaklık farkının yüksek olduğu soğutma uygulamalarında da tercih edilmektedir. Son yıllarda çevresel faktörlerin daha fazla önem kazanması ile birlikte alternatif soğutucu akışkanlar kullanımı araştırılmaktadır. Soğutma çevrimlerinde enerji tasarrufunu araştırmanın ve sağlamanın yolu her ne kadar kompresör işini minimuma indirmek gibi görünse de, birim soğutma için gerekli minimum gücü verdiği için Performans Katsayısını (COP) optimize etme üzerinde çalışmak daha cazip gelmektedir. Bu çalışmada, iki kademeli buhar sıkıştırmalı ideal bir soğutma çevriminde kullanılması durumunda farklı soğutucu akışkanların performansları parametrik olarak incelenerek mukayeseleri yapılmıştır. Buharlaşma ve yoğuşma sıcaklıklarının değişimi ile her bir akışkan için sistemin ayrı ayrı COP değerleri hesaplanmıştır. Ayrıca sistemin kompresör işi ve soğutma yüklerinin değişimleri de sunulmuştur. Sistemde en yüksek COP değeri, 6.593 ile soğutucu akışkan R600 kullanılması durumunda $5{ }^{\circ} \mathrm{C}$ buharlaşma sıcaklığında elde edilirken, en düşük değer 3.311 ile $50^{\circ} \mathrm{C}$ yoğuşma sıcaklığında R227ea kullanılması durumunda elde edilmiştir.

Anahtar Kelimeler - Çok Kademeli Soğutma Sistemleri, Performans Katsayısı, Enerji, Ekserji

\begin{abstract}
Multi-stage vapor compression refrigeration cycles are used in low temperature applications, as well as in refrigeration applications where temperature difference is high. In recent years, as environmental factors have gained more importance, the use of alternative refrigerants has been investigated. Although the way to research and achieve energy savings in refrigeration cycles seems to be minimizing compressor work, it is more attractive to work on optimizing the Coefficient of Performance (COP) as it gives the minimum power required for unit cooling. In this study, the performances of different refrigerants when used in an ideal two-stage vapor compression refrigeration cycle are analyzed parametrically and compared. Separate COP values of the system were calculated for each refrigerant by changing the evaporation and condensation temperatures. In addition, the compressor work and the changes of the cooling loads of the system are also presented. The highest COP value in the system was obtained at $5{ }^{\circ} \mathrm{C}$ evaporation temperature in case of using the refrigerant $\mathrm{R} 600$ with 6.593 , while the lowest value was obtained as 3.311 when R227ea was used at $50{ }^{\circ} \mathrm{C}$ condensation temperature.
\end{abstract}

Keywords - Multistage Refrigeration, Coefficient of Performance, Energy, Exergy

1*Sorumlu yazar iletișim: alaattinkaya@uludag.edu.tr (https://orcid.org/0000-0002-1940-8749)

Makine Mühendisliği Bölümü, Bursa Uludağ Üniversitesi, Mühendislik Fakültesi, Bursa, Türkiye. 


\section{GíRiş}

Enerji ihtiyacı ve kullanımı günden güne artmakta ve daha da önemli hale gelmektedir. Enerji tasarrufu konusunda dikkat edilmesi gereken alanlardan birisi de soğutma sistemleridir. Soğutma sistemleri için mükemmel örneği, tümden tersinir olan Carnot Çevrimi oluşturmaktadır. Carnot çevriminde, çevrimin performans katsayısı (COP), kullanılan cihazlara ve akışkanlara bağlı kalmaksızın sadece sıcaklık limitlerine bağlıdır. Soğutma uygulamalarında hedef her zaman, Carnot çevriminin performans katsayısına ulaşmak olmaktadır. Bu amaçla bazı kabuller yapılarak Tersine Carnot Çevrimi, ideal buhar sıkıştırmalı soğutma çevrimlerinde kullanılmaktadır. Düşük sıcaklık uygulamalarında ya da yüksek yoğuşma sıcaklıkları gerektiren durumlarda basit buhar sıkıştırmalı soğutma sistemleri, bazı dezavantajlara sahiptir. Yüksek sıkıştırma oranı; kompresör gücünün artması ve dolayısıyla yağlama problemlerinin oluşmasına yol açmaktadır. Ayrıca kompresör gövdesinin aşırı ısınmasına neden olur ve pistondan akışkan kaçaklarına neden olur. Kompresör girişinde artan soğutucu akışkan hacmi; kompresörün hacimsel verimini düşürmektedir. Bu durum daha büyük kompresör kullanımını gerektirmektedir. Aksi takdirde soğutma etkisi azalacaktır. Yüksek kompresör çıkış sıcaklığı; ilave yük getirmekte [1] ve yağlama yağının yanmasına neden olmaktadır [2]. Çok kademeli buhar sıkıştırmalı soğutma sistemleri uygulanarak söz konusu bu sorunlar azaltılmaya çalışılmaktadır. Buharlaşma sıcaklığı ile yoğuşma sıcaklığı arasındaki farkın $40 \mathrm{~K}$ ve daha fazla olduğu uygulamalarda [3] soğutma işlemini iki veya daha fazla kademede gerçekleştirmek başvurulan yollardan birisidir. Böyle durumlarda, birbiri ile seri olarak çalışan iki veya daha fazla soğutma çevrimini kullanan ardışık soğutma sistemleri tercih edilmektedir. Ardışık soğutma sistemlerinde alt çevrimde ve üst çevrimde farklı akışkanlar kullanılarak avantaj sağlanabilmektedir. Tek tip akışkan kullanılan durumlarda ise, bir karışma odası veya buharlaşma odası kullanılarak çok kademeli soğutma sistemleri kullanılır [4].

Çok kademeli buhar sıkıştırmalı soğutma sistemlerinde sistemin ekonomisini etkileyen önemli faktörlerden birisi de ara kademe basıncıdır. Ara kademe basıncının hangi değerde olması gerektiği ile ilgili birçok çalışma mevcuttur. Kompresör işini en aza indirgeyecek şekilde seçilebildiği gibi, soğutucu akışkanın, faz değişimlerinde ideal gaz davranışını sergilemediğini nedeniyle bu şekilde hassas olarak belirlenemeyeceğini savunan araştırmacılar da mevcuttur [5]. Saleh vd. teorik olarak, dört değişkenli parametreleri, sistemin buharlaşma ve yoğuşma sıcaklıklarını değiştirerek COP değerlerini en üst düzeye çıkarmak için çok kademeli bir buhar sıkıştırmalı soğutma çevriminin performansını araştırdı. Sistem modellemesinde Mühendislik Denklem Çözücü (EES) yazılımı kullanılmıştır ve maksimum \% 1.14 hata ile yayınlanmış verilere göre doğrulanmıştır. R717, R22, R134a, R1234yf, R1234ze (E), R410A, R404A ve R407C soğutucu akışkanlarının incelendiği çalışma sonucunda, en yüksek COP değeri amonyak kullanılması durumunda (6.17) elde edilirken, minimum COP değeri R407C ile elde edilmiştir (4.95). Optimizasyon sonuçları ayrıca, R717'nin tüm soğutucu akışkanlarla karşılaştırıldığında en iyi seçenek olduğunu söylerken, R407C'nin kullanılması önerilmemiştir [6]. Liu vd. sabit kompresör çıkış basıncında ve en uygun soğutma sıcaklığı koşullarında beş farklı soğutma sistemi için iki kademeli soğutma çevriminin performans analizlerini yaptılar. Analizleri sonucunda, tek kısılma vanası kullanılan iki kademeli soğutma sistemi en yüksek enerji tüketimine sahipken, iki kısılma vanası kullanılan sistemin en iyi performansa sahip olduğunu buldular [7]. Voloshchuk, iki kademeli, buhar sıkıştırmalı bir sistemin termodinamik hesaplamalarını bilgisayar programı yazarak yapmış ve kullanılan bağıntıları ve hesaplama sonuçlarını paylaşmıştır [8]. Xuan, çok kademeli bir soğutma sisteminin analizlerini yaparak, termoelektrik malzemelerin de hesaba katılması gerektiği sonucuna varmıştır ve termoelektrik özelliklerin sıcaklık bağımsızlıkları açısından incelendiğinde, birçok kademeli termoelektrik soğutucunun en uygun ara kademe parametresinin elektriksel konfigürasyonundan bağımsız olduğunu bulmuşlardır [9]. Nikolaidis vd. soğutucu akışkan R22 kullanılan iki kademeli buhar sıkıştırmalı soğutma sisteminin performansı için, ekserji analizi yaptı ve buharlaşma ve yoğuşma sıcaklıklarındaki değişimin, sistemin tersinmezlikleri açısından çok önemli olduğu sonucuna varmışlardır [10]. Prasad, R12 soğutucu akışkanı için iki kademeli soğutma çevrimlerinde, en yüksek COP değerini verecek, en uygun ara kademe basıncını belirlediği çalışmasında en uygun ara kademe basıncının, buharlaşma ve yoğuşma basınçlarının geometrik ortalaması olduğunu bulmuştur [11]. Zubair ve Khan [12], optimum ara kademe basıncının, buharlaştırıcı ve yoğuşturucu sıcaklıklarının aritmetik ortalaması olan sıcaklığa karşıllk gelen doyma basıncına çok yakın olduğunu bulmuşlardır. Zubair vd. R134a için en yüksek COP değerini verecek en uygun ara kademe basıncının, buharlaşma ve yoğuşma basınçlarının aritmetik ortalamasına yakın olduğunu göstermişlerdir[13]. Ratts ve Brown[14], iki kademeli buhar sıkıştırmalı soğutma çevrimi için, entropi üretimi minimizasyon metodunu kullanarak en uygun ara kademe sıcaklığını R134a kullanılması durumunda belirlemişlerdir ve bu yöntemin, R502 ile kıyaslandığında, geometrik ortalama ile bulunan ara kademe sıcaklığından daha iyi sonuçlar verdiği sonucuna varmışlardır. 
Soğutma çevrimlerinde enerji tasarrufunu araştırmanın ve sağlamanın yolu her ne kadar kompresör işini minimuma indirmek gibi görünse de, birim soğutma için gerekli minimum gücü verdiği için COP optimize etme üzerinde çalışmak daha cazip gelmektedir. COP değerini incelemek, sistemin enerji korunumu hakkında yeterli bilgiyi verir fakat sistem performansının nasıl, nerede ve ne kadar düştüğü de araştırılmak istendiğinde ekserji analizi de incelenmelidir [15]. Küresel ısınma ile mücadele yıllardır sürdürülen ve gittikçe artan tedbirler ile devam eden bir konudur. 1997 yllında imzalanan Kyoto Protokolü, küresel 1sınma ve iklim değişikliği ile mücadele konusunda imzalanan ilk uluslararası anlaşmadır. Birleşmiş Milletler üyesi bütün ülkelerin imzaladığı Montreal Protokolü'ne göre, ozon tükenme potansiyeli (ODP) olan kimyasalların kullanımını yasaklamakta ve azaltılmalıdır. Kigali Antlaşması'nda ise, hidroflorokarbonların (HFCs) tüketiminin ve üretiminin kademeli olarak azaltılması konusunda fikir birliğine varılmıştır. Paris Antlaşması'nda da benzer olarak gelişmiş ülkeler, iklim değişikliğine neden olan kimyasalların kullanımını azaltacaklarını beyan etmişlerdir. On yıllardır küresel ısınma ile mücadele sürmektedir. Küresel ısınma ile mücadele kapsamında, soğutma çevrimlerinde kullanılan soğutucu akışkanlar önemli bir yer tutmaktadır. Soğutucu akışkanlardan bazıları yasaklanmakta, bir kısmı ise kademeli olarak kullanımdan kaldırılmaktadır. Soğutucu akışkanların ODP, Küresel Isınma Potansiyeli (GWP) veya parlayıcılığı nedeni ile kaçak problemlerinin olmaması için ilave güvenlik tedbirleri gerektirdiklerinden ikame soğutucu akışkan bulma konusunda arayış yıllardan beri süregelmektedir ve bu konuda birçok çalışma yapılmaktadır. Günümüzde de, hem alternatif soğutucu akışkan bulma çabası hem de enerji tasarrufu açısından, farklı şartlarda farklı akışkanların kullanılması daha fazla fayda sağlayacağından benzer çalışmalar devam etmektedir ve küresel ısınma konusunda hassasiyet sürdükçe en verimli soğutucu akışkan-sistem bulma çalışmaları da sürecektir. Bu çalışmada da, kaynama sıcaklıkları yakın soğutucu akışkanlardan $\left(-10^{\circ} \mathrm{C}\right.$ ile $-40{ }^{\circ} \mathrm{C}$ arasında) ODP değerleri sıfır ve sıfira yakın R22, R1234yf, R227ea ve R600 soğutucu akışkanları kullanılarak, iki kademeli buhar sıkıştırmalı ideal bir soğutma çevriminin enerji ve ekserji analizleri yapılmış̧ır. Sistem modellemesi Mühendislik Denklem Çözücüsü yazılımı kullanılarak tamamlandı. Modelleme için yazılan programın doğruluğunu test etmek amacı ile literatürdeki diğer çalışmalar, yazılan kod ile çalıştırılarak benzer sonuçlar elde edildiği gözlemlenerek hesaplamalarda kullanılmıştır. Buharlaşma ve yoğuşma sıcaklıklarının değişimi ile her bir akışkan için sistemin ayrı ayrı COP değerleri ve ekserji yıkımları hesaplanmıştır. Ayrıca sistemin kompresör işi ve soğutma yüklerinin değişimleri de sunulmuştur.

\section{MATERYAL VE METOT}

\section{A. Sistem}

Şekil 1'de şematik görünümü sunulan iki kademeli buhar sıkıştırmalı soğutma çevriminde tek akışkan kullanılmaktadır. Akışkan önce alçak basınç kompresöründe, ardından buharlaşma odasında oluşan buhar ile birlikte yüksek basınç kompresöründe sıkıştırılarak yoğuş̧turucuya gönderilir. Burada isısını dış ortama veren soğutucu akışkan doymuş sıvı olarak yoğuşturucuyu terk eder. Birinci genleşme vanasından geçen soğutucu akışkanın basıncı ve sıcaklığı düşer. Ani basınç düşüşü esnasında meydana gelen buhar kısmı, alçak basınç kompresöründen gelen kızgın buhar halindeki buhar ile birleşerek tekrar yüksek basınç kompresörüne gönderilir. Birinci genleşme vanasından geçen soğutucu akışkanın sıvı kısmı ise ikinci genleşme vanasından geçerek doymuş sıvı-buhar karışımı fazında buharlaş̧ıııcıya gönderilir. Buharlaştırıııdan doymuş buhar fazında çıkan soğutucu akışkan, alçak basınç kompresörüne gönderilir ve kompresörde basıncı ve sıcaklığı artırılarak karışma odasına gönderilir.

Hesaplamalarda ara kademe basıncının bulmak için kullanılan eşitlik Denklem 1'de sunulmuştur.

$$
P_{i}=\sqrt{P_{c} \cdot P_{e}}
$$

Burada ara kademe basıncı $(\mathrm{Pi})$, yoğuşturucu basıncı $(\mathrm{Pc})$ ve buharlaştırıı basıncının $(\mathrm{Pe})$ geometrik ortalaması şeklinde alınmıştır. Hesaplama koşulları Tablo 1'de sunulmaktadır. 


\begin{tabular}{|c|c|c|}
\hline & $\begin{array}{l}\text { BŞEÜ Fen Bilimleri Dergisi } \\
8(1), 42-55,2021\end{array}$ & $\begin{array}{r}\text { BSEU Journal of Science } \\
\text { https://doi.org/10.35193/bseufbd.826970 }\end{array}$ \\
\hline & & 2458-7575 (https://dergipark.org.tr/tr/pub/bseufbd) \\
\hline
\end{tabular}

Tablo 1. Analiz Koşulları

\begin{tabular}{l|l|l|l}
\hline & Sembol & Değer & Birim \\
\hline Yoğuşturucu Sıcaklığı & $\mathrm{T}_{\mathrm{c}}$ & 37 & ${ }^{\circ} \mathrm{C}$ \\
Buharlaştırıcı Sıcaklığı & $\mathrm{T}_{\mathrm{e}}$ & -3 & ${ }^{\circ} \mathrm{C}$ \\
Alçak Basınç Kompresörü Verimi & $\mu_{A B K}$ & 82 & $\%$ \\
Yüksek Basınç Kompresörü Verimi & $\mu_{Y B K}$ & 82 & $\%$ \\
Ortam Basıncı & $\mathrm{P}_{\mathrm{a}}$ & 1 & $\mathrm{~atm}$ \\
Soğutulan Ortam Giriş - Çıkış Sıcaklığı & $\mathrm{T}_{\mathrm{a}}$ & $15-10$ & ${ }^{\circ} \mathrm{C}$ \\
Isı atılan Ortam Giriş - Çıkış Sıcaklığı & $\mathrm{T}_{\mathrm{w}}$ & $20-25$ & ${ }^{\circ} \mathrm{C}$ \\
Soğutucu Akışkan Debisi & $\dot{m}$ & 0,1 & $\mathrm{~kg} / \mathrm{s}$ \\
\hline
\end{tabular}

Ara kademe sıcaklığı belirlenmesinde, önce yoğuşturucu sıcaklığına karşılık gelen doyma basıncı olan yoğuşturucu basıncı belirlenir. Aynı şekilde buharlaştırıcı sıcaklığına karşılık gelen doyma basıncı olan buharlaştırıcı basıncı belirlenir. Daha sonra geometrik ortalamaları ile ara kademe basıncı belirlenir. Ara kademe basıncına karşılık gelen doyma sıcaklığı olan ara kademe sıcaklığı belirlenir ve analizler yapılmaya başlanır.

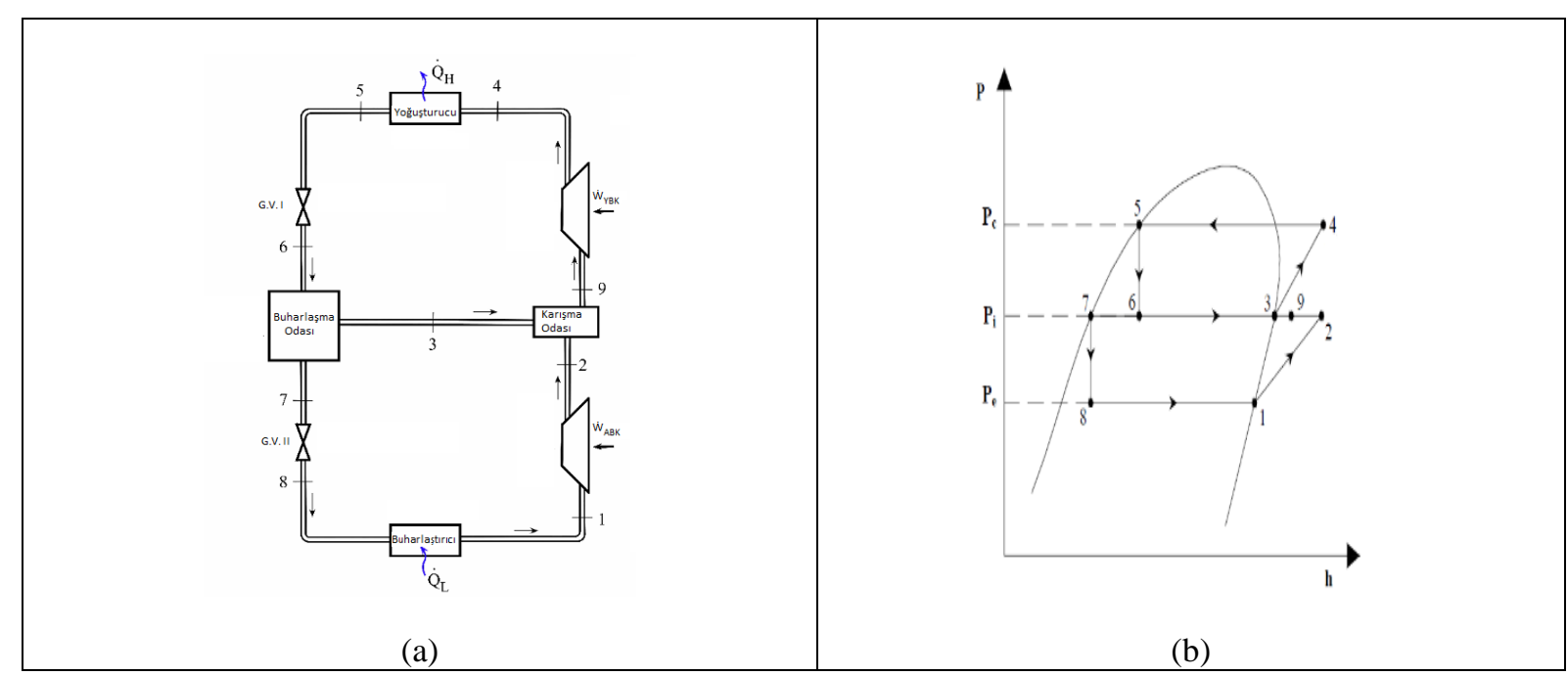

Şekil 1. İki kademeli buhar sıkıştırmalı soğutma çevrimi ile T-s ve P-h diyagramları

Şekil 1'de hesaplamaları yapılan iki kademeli buhar sıkıştırmalı soğutma çevrimine ait şematik görünüm (a) ve P-h diyagramı (b) sunulmuştur.

\section{B. Soğutucu Akışkanlar}

Çalışmada kullanılan soğutucu akışkanlara ait özellikler Tablo 2'de sunulmaktadır. ODP değerleri sıfır olan üç farklı soğutucu akışkanla birlikte, 0.05 olan R22 soğutucu akışkanı da incelenmiştir.

Tablo 2. Soğutucu akışkanların özellikleri

\begin{tabular}{|c|c|c|c|c|c|c|c|c|}
\hline \multirow{2}{*}{$\begin{array}{l}\text { Soğutucu } \\
\text { Akışkan }\end{array}$} & \multirow[b]{2}{*}{ Kimyasal Formül } & \multicolumn{4}{|c|}{ Fiziksel Faktörler } & \multicolumn{3}{|c|}{ Çevresel Faktörler } \\
\hline & & $\begin{array}{c}\mathbf{M} \\
\mathrm{g} / \mathrm{mol}\end{array}$ & $\begin{array}{c}\text { NBP } \\
{ }^{\circ} \mathrm{C}\end{array}$ & $\begin{array}{l}\mathbf{T}_{\mathbf{c}} \\
{ }^{\circ} \mathbf{C}\end{array}$ & $\begin{array}{c}\mathbf{P}_{\mathrm{c}} \\
\mathbf{M P a}\end{array}$ & ALT & ODP & $\begin{array}{c}\text { GWP } 100 \\
y r\end{array}$ \\
\hline R1234yf & $\mathrm{C}_{3} \mathrm{H}_{2} \mathrm{~F}_{4}$ & 114 & -29.4 & 94,7 & 3.382 & 0.03 & 0 & 4 \\
\hline $\mathrm{R} 22$ & $\mathrm{CHClF}_{2}$ & 86.5 & -40.7 & 96.14 & 4.990 & 12 & 0.05 & 1.760 \\
\hline R227ea & $\mathrm{C}_{3} \mathrm{HF}_{7}$ & 170 & -16.4 & 102.8 & 2.980 & 34.2 & 0 & 3.350 \\
\hline R600 & $\mathrm{CH}_{3} \mathrm{CH}_{2} \mathrm{CH}_{2} \mathrm{CH}_{3}$ & 58.1 & -11.7 & 152.01 & 3.796 & 12 & 0 & 4 \\
\hline
\end{tabular}




\section{Termodinamik Analiz}

Çalışmada, sistemin kararlı olduğu, sistem borularında meydana gelen basınç kayıplarının ihmal edildiği, soğutucu akışkanların buharlaştırıııda, yoğuşturucuda ve alçak basınç kompresörü girişinde doymuş halde olduğu kabuller yapılarak 1sıl kapasiteler belirlenmesi için aşağıdaki kütle ve enerji denge denklemleri kullanılmıştır. Tablo 3'te sistemin elemanlarında enerji ve ekserji hesaplamaları için kullanılan denklemler sunulmaktadır.

Tablo 3. Termodinamik analiz denklemleri

\begin{tabular}{|c|c|c|}
\hline & Enerji & Ekserji \\
\hline Buharlaştıııcı & $\dot{Q}_{L}=\dot{m}_{8}\left(h_{1}-h_{8}\right)$ & $\dot{E} x_{8}+\dot{E} x_{12}=\dot{E} x_{1}+\dot{E} x_{13}+\dot{E} x_{d e s t, E}$ \\
\hline Yoğuşturucu & $\dot{Q}_{H}=\dot{m}_{4}\left(h_{4}-h_{5}\right)$ & $\dot{E} x_{4}+\dot{E} x_{10}=\dot{E} x_{5}+\dot{E} x_{11}+\dot{E} x_{d e s t, ~}$ \\
\hline Yüksek Basınç Kompresör Gücü & $\dot{W}_{A B K}=\dot{m}_{1}\left(h_{2}-h_{1}\right)$ & $\dot{W}_{Y B K}+\dot{E} x_{9}=\dot{E} x_{4}+\dot{E} x_{d e s t, Y B K}$ \\
\hline Alçak Basınç Kompresör Gücü & $\dot{W}_{Y B K}=\dot{m}_{9}\left(h_{4}-h_{9}\right)$ & $\dot{W}_{A B K}+\dot{E} x_{1}=\dot{E} x_{2}+\dot{E} x_{d e s t, A B K}$ \\
\hline Genleşme Vanası I: & $h_{6}=h_{5}$ & $\dot{E} x_{5}=\dot{E} x_{6}+\dot{E} x_{d e s t, G V 1}$ \\
\hline Genleşme Vanası II: & $h_{7}=h_{8}$ & $\dot{E} x_{7}=\dot{E} x_{8}+\dot{E} x_{\text {dest }, G V 2}$ \\
\hline Buharlaşma Odası & $\dot{m}_{6} h_{6}=\dot{m}_{7} h_{7}+\dot{m}_{3} h_{3}$ & $\dot{E} x_{6}=\dot{E} x_{7}+\dot{E} x_{d e s t, B O}$ \\
\hline Karışma Odası: & $\dot{m}_{9} h_{9}=\dot{m}_{2} h_{2}+\dot{m}_{3} h_{3}$ & $\dot{E} x_{3}+\dot{E} x_{2}=\dot{E} x_{9}+\dot{E} x_{d e s t, K O}$ \\
\hline Toplam Kompresör Gücü & $\dot{W}_{N E T}=\dot{W}_{A B K}+\dot{W}_{Y B K}$ & \\
\hline Performans Katsayıs1 & $C O P=\frac{\dot{Q}_{L}}{\dot{W}_{N E T}}$ & \\
\hline
\end{tabular}

\section{BULGULAR VE TARTIŞMA}

\section{A. Doğrulama}

Çalışma esnasında kullanılan ve hesaplamaların yapıldığı kodun doğruluğu literatürde mevcut olan bir çalışmanın sonuçlarının tekrarlanması yöntemi ile gösterilmiştir. Kapil vd. [16] tarafından yayınlanan çalışma sonuçları, yoğuşturucu sıcaklığ $45^{\circ} \mathrm{C}$ 'de sabit tutularak, \% 80 kompresör verimi şartlarında soğutucu akışkan R600 için, buharlaştırıcı sıcaklı̆ ${ }^{-}-50^{\circ} \mathrm{C}$ 'den $5^{\circ}{ }^{\circ}$ 'ye değiştirilerek tekrarlanmıştır. Elde edilen sonuçlar ile diğer çalışmanın sonuçları Şekil 2'de sunulmaktadır. Sonuçlarda, önemli farklılık görülmediği için, makul fark ile çalışma yapılmıştır.

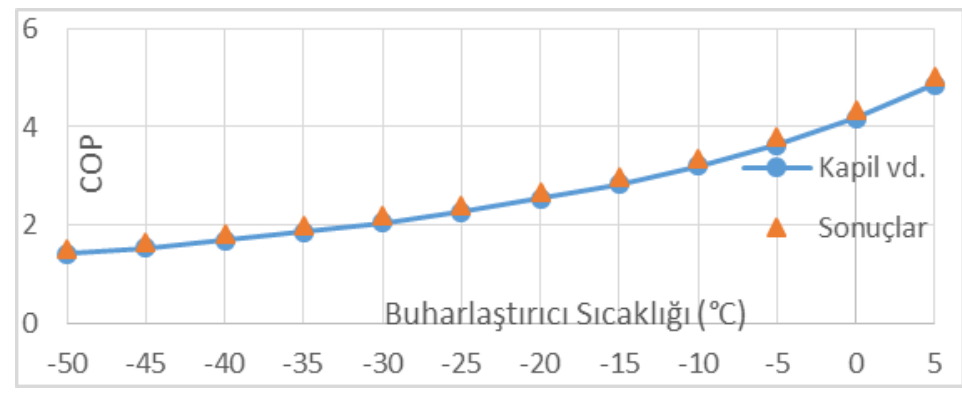

Şekil 2. Doğrulama çalışmaları 


\begin{tabular}{|c|c|c|}
\hline & $\begin{array}{l}\text { BŞEÜ Fen Bilimleri Dergisi } \\
8(1), 42-55,2021\end{array}$ & $\begin{array}{r}\text { BSEU Journal of Science } \\
\text { https://doi.org/10.35193/bseufbd.826970 }\end{array}$ \\
\hline $\begin{array}{l}\text { BILECIKSEYY EDEBA A } \\
\text { UNIVERSITES }\end{array}$ & & 2458-7575 (https://dergipark.org.tr/tr/pub/bseufbd) \\
\hline
\end{tabular}

\section{B. Sonuçlar}

Gerçekleştirilen analizlerin sonuçları ve soğutucu akışkanlara ait T-s grafikleri, aşağıda sunulmaktadır. Tablo 4'te R22'ye ait sonuçlar sunulmaktadır. Buharlaştırıcı basıncı 451,3 kPa, yoğuşturucu basıncı $1425 \mathrm{kPa}$ ve ara kademe basıncı bu değerlerin geometrik ortalaması $801,9 \mathrm{kPa}$ olarak hesaplanmıştır ve Tablo 4'te sunulmaktadır. T-s diyagramında basınç kademelerinin gösterimi Şekil 3’te görülmektedir.

Tablo 4. R22 Analiz Sonuçları

\begin{tabular}{llllll} 
& $\mathbf{P}(\mathbf{k P a})$ & $\mathbf{T}\left({ }^{\circ} \mathbf{C}\right)$ & $\mathbf{h}(\mathbf{k J} / \mathbf{k g})$ & $\dot{\boldsymbol{m}}(\mathbf{k g} / \mathbf{s})$ & $\mathbf{x}$ \\
\hline 1 & 451,3 & -3 & 403,8 & 0,08582 & 1 \\
\hline 2 & 801,9 & 28,64 & 420,8 & 0,08582 & - \\
\hline 3 & 801,9 & 15,53 & 410,3 & 0,01418 & 1 \\
\hline 4 & 1425 & 61,1 & 437,5 & 0,1 & - \\
\hline 5 & 1425 & 37 & 245,8 & 0,1 & 0 \\
\hline 6 & 801,9 & 15,53 & 245,8 & 0,1 & 0,1418 \\
\hline 7 & 801,9 & 15,53 & 218,7 & 0,08582 & 0 \\
\hline 8 & 451,3 & -3 & 218,7 & 0,08582 & 0,107 \\
\hline 9 & 801,9 & 26,74 & 419,3 & 0,1 & -
\end{tabular}

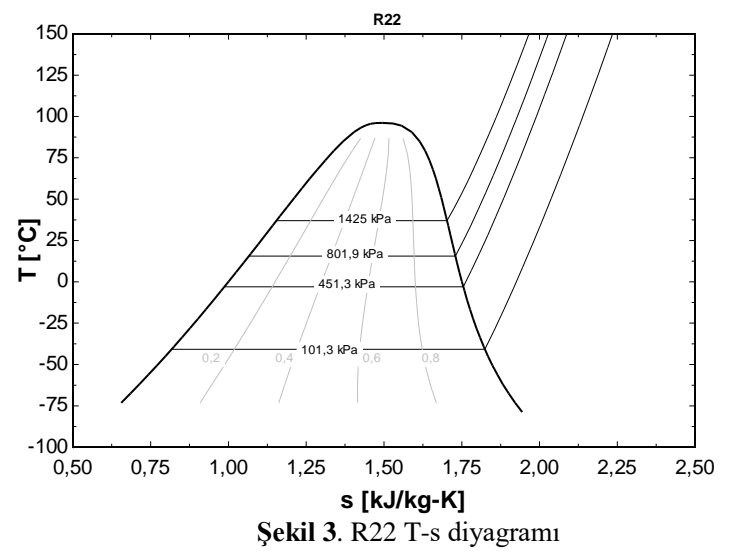

Tablo 5'te R1234yf soğutucu akışkanına ait analiz sonuçları sunulmaktadır. Buharlaştırıcı basıncı 284,9 $\mathrm{kPa}$, yoğuşturucu basıncı $943 \mathrm{kPa}$ ve ara kademe basıncı da 518,4 kPa olarak hesaplanmıştır. T-s diyagramında basınç kademelerinin gösterimi Şekil 4'te görülmektedir.

Tablo 5. R1234yf Analiz Sonuçları

\begin{tabular}{llllll}
\cline { 2 - 5 } & $\mathbf{P}(\mathbf{k P a})$ & $\mathbf{T}\left({ }^{\circ} \mathbf{C}\right)$ & $\mathbf{h}(\mathbf{k J} / \mathbf{k g})$ & $\dot{\boldsymbol{m}}(\mathbf{k g} / \mathbf{s})$ & $\mathbf{x}$ \\
\hline 1 & 284,9 & -3 & 361,3 & 0,08058 & 1 \\
\hline 2 & 518,4 & 16,73 & 374,4 & 0,08058 & \\
\hline 3 & 518,4 & 15,53 & 373,1 & 0,01942 & 1 \\
\hline 4 & 943 & 38,43 & 387,2 & 0,1 & \\
\hline 5 & 943 & 37 & 249,4 & 0,1 & 0 \\
\hline 6 & 518,4 & 15,53 & 249,4 & 0,1 & 0,1942 \\
\hline 7 & 518,4 & 15,53 & 219,6 & 0,08058 & 0 \\
\hline 8 & 284,9 & -3 & 219,6 & 0,08058 & 0,1454 \\
\hline 9 & 518,4 & 16,48 & 374,1 & 0,1 &
\end{tabular}

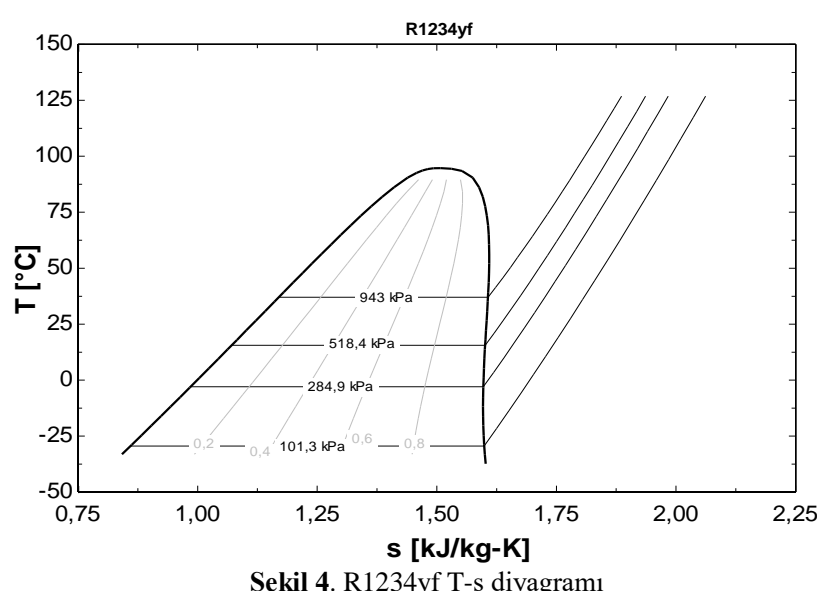

Tablo 6'da R227ea soğutucu akışkanına ait analiz sonuçları sunulmaktadır. Buharlaştıııı basıncı 173,7 $\mathrm{kPa}$, yoğuşturucu basıncı 644,2 kPa ve ara kademe basıncı da 334,5 kPa olarak hesaplanmıştır. T-s diyagramında basınç kademelerinin gösterimi Şekil 5'te görülmektedir. 
Tablo 6. R227ea Analiz Sonuçları

\begin{tabular}{llllll}
\cline { 2 - 5 } & $\mathbf{P}(\mathrm{kPa})$ & $\mathbf{T}\left({ }^{\circ} \mathrm{C}\right)$ & $\mathbf{h}(\mathrm{kJ} / \mathrm{kg})$ & $\dot{\boldsymbol{m}}(\mathrm{kg} / \mathrm{s})$ & $\mathbf{x}$ \\
\hline 1 & 173,7 & -3 & 142,2 & 0,07807 & 1 \\
\hline 2 & 334,5 & 15,45 & 152 & 0,07807 & \\
\hline 3 & 334,5 & 15,45 & 154 & 0,02193 & 1 \\
\hline 4 & 644,2 & 37 & 162,1 & 0,1 & \\
\hline 5 & 644,2 & 37 & 63,01 & 0,1 & 0 \\
\hline 6 & 334,5 & 15,45 & 63,01 & 0,1 & 0,2193 \\
\hline 7 & 334,5 & 15,45 & 37,45 & 0,07807 & 0 \\
\hline 8 & 173,7 & -3 & 37,45 & 0,07807 & 0,1661 \\
\hline 9 & 334,5 & 15,45 & 152,4 & 0,1 &
\end{tabular}

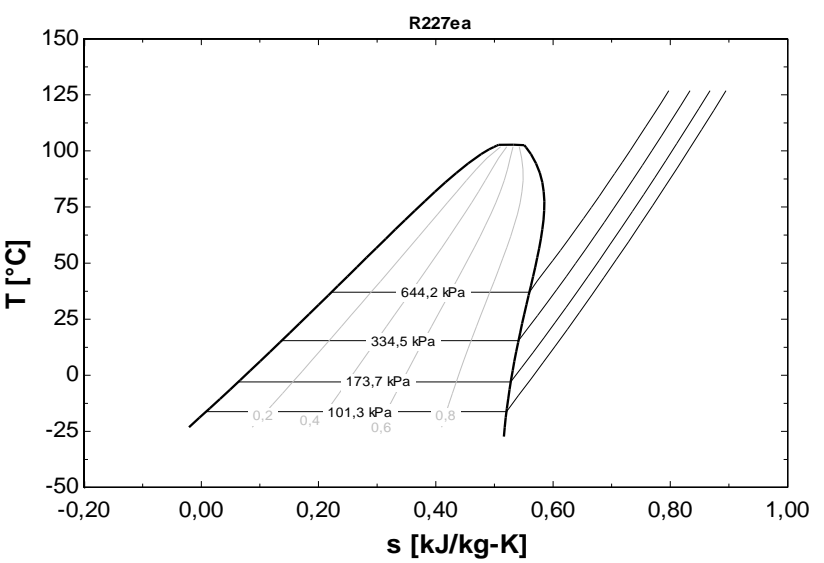

Şekil 5. R227ea T-s diyagramı

Tablo 7. R600 Analiz Sonuçları

\begin{tabular}{llllll}
\cline { 2 - 5 } & $\mathbf{P}(\mathrm{kPa})$ & $\mathbf{T}\left({ }^{\circ} \mathrm{C}\right)$ & $\mathbf{h}(\mathrm{kJ} / \mathrm{kg})$ & $\dot{\boldsymbol{m}}(\mathrm{kg} / \mathrm{s})$ & $\mathbf{x}$ \\
\hline 1 & 92,12 & -3 & 580,3 & 0,0858 & 1 \\
\hline 2 & 179,2 & 18,03 & 611 & 0,0858 & \\
\hline 3 & 179,2 & 15,46 & 606,5 & 0,0142 & 1 \\
\hline 4 & 348,4 & 39,8 & 642,5 & 0,1 & \\
\hline 5 & 348,4 & 37 & 289 & 0,1 & 0 \\
\hline 6 & 179,2 & 15,46 & 289 & 0,1 & 0,14 \\
\hline 7 & 179,2 & 15,46 & 236,4 & 0,0858 & 0 \\
\hline 8 & 92,12 & -3 & 236,4 & 0,0858 & 0,11 \\
\hline 9 & 179,2 & 17,66 & 610,4 & 0,1 &
\end{tabular}

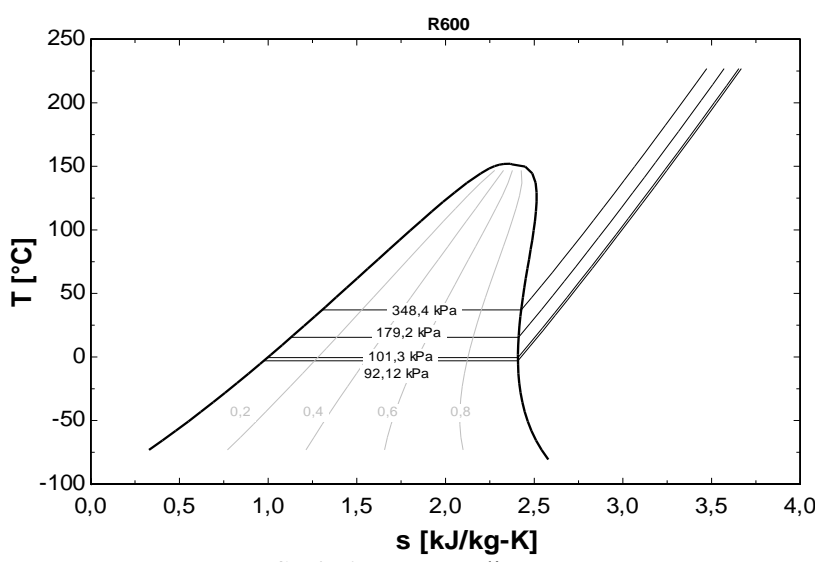

Şekil 6. R600 T-s diyagramı

Tablo 7'de R600 soğutucu akışkanına ait analiz sonuçları sunulmaktadır. Buharlaştırıcı basıncı 92,12 kPa, yoğuşturucu basıncı 348,4 kPa ve ara kademe basıncı da 179,2 kPa olarak hesaplanmıştır. T-s diyagramında basınç kademelerinin gösterimi Şekil 6'da görülmektedir.

Tablo 8. Soğutucu Akışkanların Performans Analizleri

\begin{tabular}{lcccc} 
& COP & $\dot{\boldsymbol{Q}}_{\boldsymbol{H}}$ & $\dot{\boldsymbol{Q}}_{\boldsymbol{L}}$ & $\dot{\boldsymbol{W}}_{\boldsymbol{N E T}}$ \\
\hline R22 & 4,861 & 19,16 & 15,89 & 3,269 \\
& & & & \\
\hline R1234yf & 4,83 & 13,78 & 11,42 & 2,364 \\
& & & & \\
\hline R227ea & 4,735 & 9,904 & 8,177 & 1,727 \\
\hline R600 & 5,04 & 35,35 & 29,5 & 5,853
\end{tabular}

Tablo 8'de soğutucu akışkanlara ait, mevcut analiz koşullarında hesaplanan değerler sunulmaktadır. Burada en düşük kompresör işinin R227ea soğutucu akışkanına ait olduğu, diğer taraftan en küçük soğutma yüküne sahip ve yine en düşük performans katsayısına sahip olduğu görülmektedir. Soğutucu akışkanların soğutma yükleri değerleri arasında fark yüksek görünse de performans katsayıları arasındaki farkın çok büyük olmadığı görülmektedir. 


\begin{tabular}{|c|c|c|}
\hline & $\begin{array}{l}\text { BŞEÜ Fen Bilimleri Dergisi } \\
8(1), 42-55,2021\end{array}$ & $\begin{array}{r}\text { BSEU Journal of Science } \\
\text { https://doi.org/10.35193/bseufbd.826970 }\end{array}$ \\
\hline & & 2458-7575 (https://dergipark.org.tr/tr/pub/bseufbd) \\
\hline
\end{tabular}

\section{Parametrik Enerji Analizi}

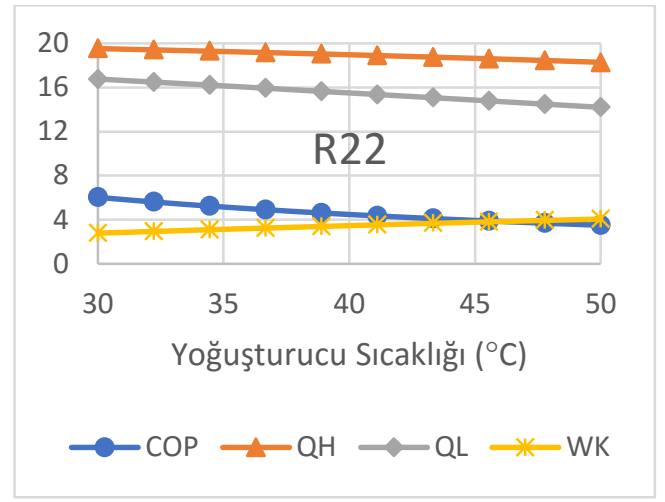

(a)

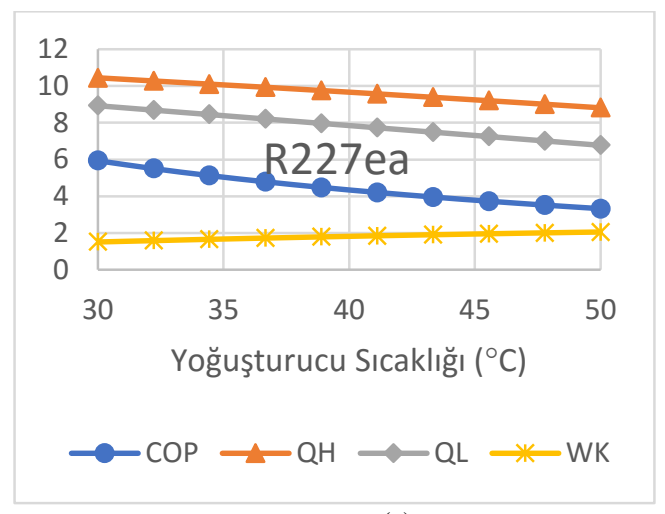

(c)

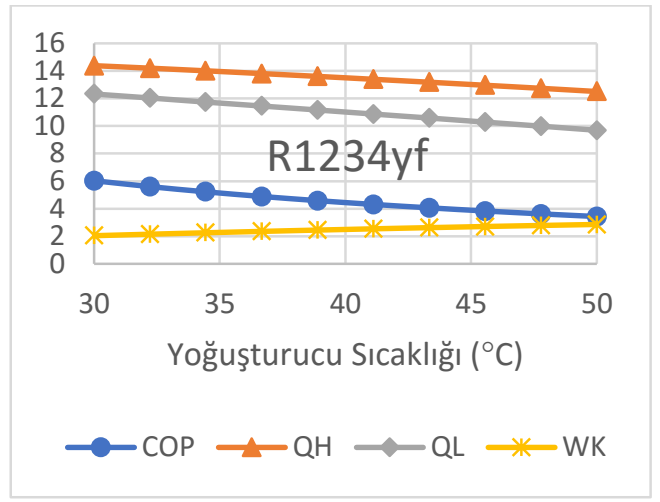

(b)

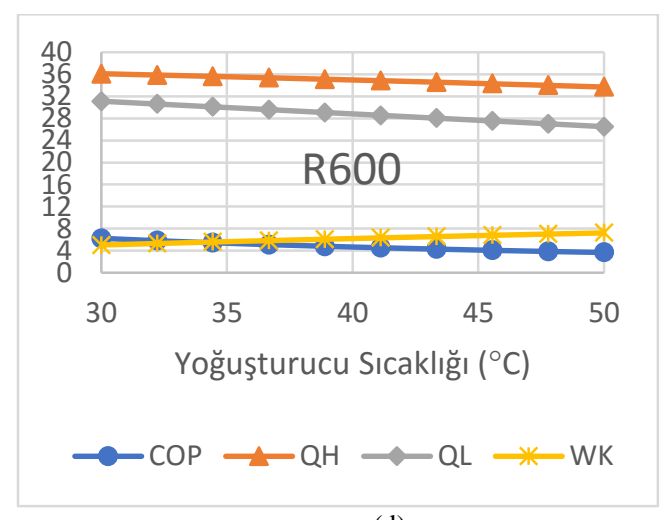

(d)

Şekil 7. Yoğuşturucu Sıcaklığı değişiminin sistem performansına etkisi

Yoğuşturucu sıcaklığının değişiminin sistemin performansına etkisini incelemek amacı ile değişik yoğuşturucu sıcaklıklarında analizler tamamlanmıştır. Sistemdeki bütün değerlerin Tablo 1'de sunulan değerlerde sabit tutulup sadece yoğuşturucu sicaklığının $30{ }^{\circ} \mathrm{C}$ 'den $50{ }^{\circ} \mathrm{C}$ 'ye kadar değişimlerinde sistemin performans değişimi Şekil 7'de sunulmaktadır. Şekil 7'de R22 (a), R1234yf (b), R227ea (c) ve R600 (d) soğutucu akışkanları için, değişen yoğuşturucu sıcaklığının sistem üzerinde etkisi görülmektedir. Yoğuşturucu sıcaklığının artışı ile literatürde çoğu çalışmaya benzer olarak beklendiği gibi kompresör işi artmakta, dolayısıyla sistemin COP değeri azalmaktadır. Şekil 8 (a)'da artan yoğuşturucu sıcaklığı ile COP değerinin değişimi sunulmakla birlikte, Şekil 7'de söz konusu değişimin nedeni ayrıntılı olarak gösterilmektedir. Şekil 7 (d)'de, en büyük kompresör işi R600 için 7,24 kW (R227ea'nın 3,5 kat1, R1234yf'nin 2,5 kat1, R22'nin 1,8 katı) olarak hesaplanması ile birlikte, sistemin COP değeri, diğer soğutucu akışkan kullanılan sistemlere göre en yüksek olarak çıkmaktadır. Şekil 8 (a)'da, en yüksek COP değerinin 6,222 ile R600 soğutucu akışkanının, en düşük yoğuşturucu sıcaklığında hesaplanmıştır. En düşük değerin ise R227ea ile en yüksek yoğuşturucu sıcaklığında 3,311 olarak hesaplanmıştır. Analiz sonuçlarına bakıldığında R22 ile R1234yf değerlerinin birbirine çok yakın çıktığı, R227ea değerlerinin ise en düşük seviyede olduğu gözlemlenmiştir. Çevrim değerlerinin Tablo 1'deki değerler olarak alındığı ve $-15^{\circ} \mathrm{C}$ ile $5{ }^{\circ} \mathrm{C}$ arasında değiştirilen buharlaştırıcı sıcaklıklarında sistem performans değişimi Şekil 9' da sunulmaktadır. Burada, bütün soğutucu akışkanlar için, artan buharlaştırıcı sıcaklığı neticesinde kompresör işinin azalması ve dolayısıyla COP arttığı (literatürde geçerli olan durum) görülmektedir. Şekil 8 (a) incelendiğinde R600 soğutucu akışkanı, diğer soğutucu akışkanlara göre \%3'ten daha yüksek COP farklı değerlerine sahip olduğu görülmektedir. $\mathrm{Bu}$ sonuçlar, literatürdeki çalışmalarda araştırmacıların; azalan yoğuşturucu sıcaklığı ile ekserji yıkımının da azaldığı [17], buharlaştırcı sıcaklığının tersine, artan yoğuşturucu sicaklı̆̆ı ile hem COP hem de ekserji verimlerinin azaldığı [18], ekserji kayıplarının arttığı [14], ekserji yıkımının azaldığı [16], ekserji veriminin azaldığg [19] ve ekserji kayıplarının arttığı sonuçları [20] ile uyum sağlamaktadır. 


\begin{tabular}{|c|c|c|}
\hline & $\begin{array}{l}\text { BŞEÜ Fen Bilimleri Dergisi } \\
8(1), 42-55,2021\end{array}$ & $\begin{array}{r}\text { BSEU Journal of Science } \\
\text { https://doi.org/10.35193/bseufbd.826970 }\end{array}$ \\
\hline & & 2458-7575 (https://dergipark.org.tr/tr/pub/bseufbd) \\
\hline
\end{tabular}

Şekil 8 (b)'de değişen buharlaştırıcı sıcaklıkları ile sistemin performans katsayısının değişimi sunulmaktadır. Yine beklendiği gibi buharlaştırıcı sıcaklığının artması ile sistemin performans katsayısının arttığı görülmektedir. Bu sonuç, buharlaştırıcı sıcaklığının artışı ile ekserji verimi artacaktır [17], ekserji kayıpları azalacaktır [16], [19]-[21] ve ekserji kayıpları daha düşük çıkacaktır [22] sonuçları ile uyum halindedir. En yüksek performans katsayısı değeri 6,593 değeri ile R600 soğutucu akışkanının $5{ }^{\circ} \mathrm{C}$ sıcaklık değerinde elde edilirken, en düşük değeri ise 3,341 ile R227ea akışkanının $-15^{\circ} \mathrm{C}$ sıcaklığındaki değerinde hesaplanmıştır.

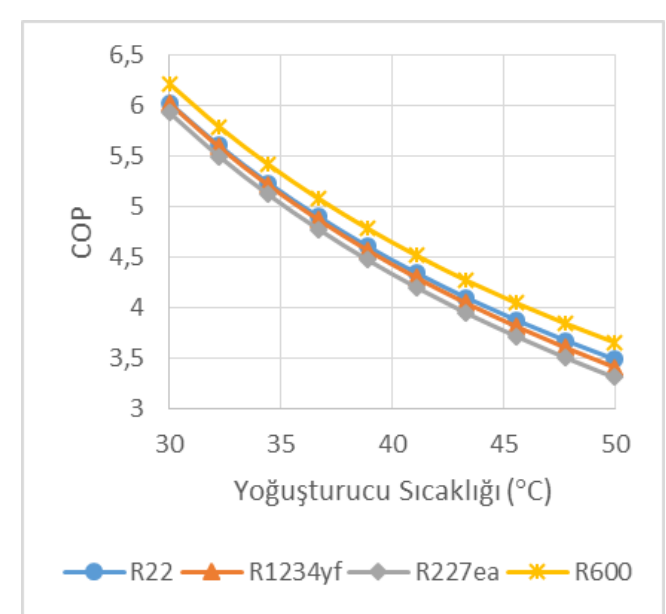

(a)

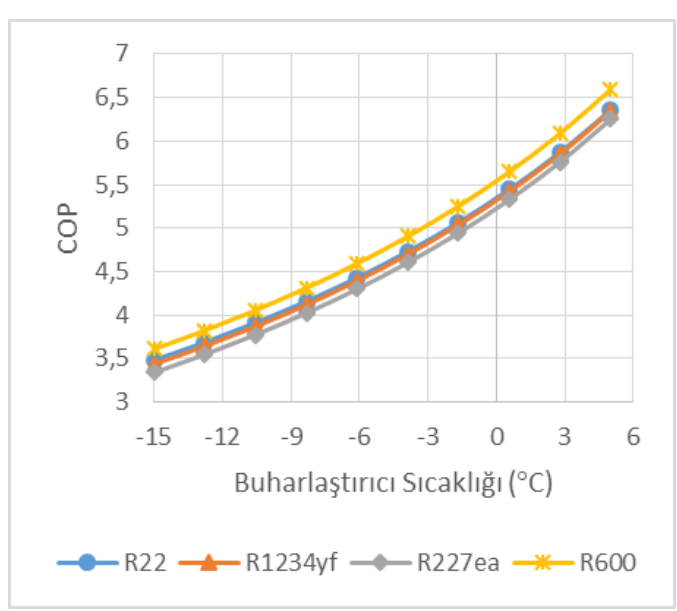

(b)

Şekil 8. Yoğuşturucu sıcaklığı- Performans Katsayısı değişimi (a) ve Buharlaştırıcı sıcaklığı - Performans Katsayısı değişimi (b)

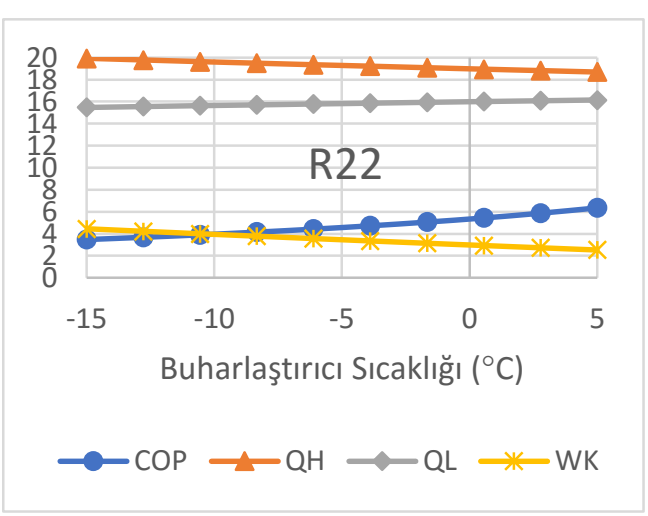

(a)

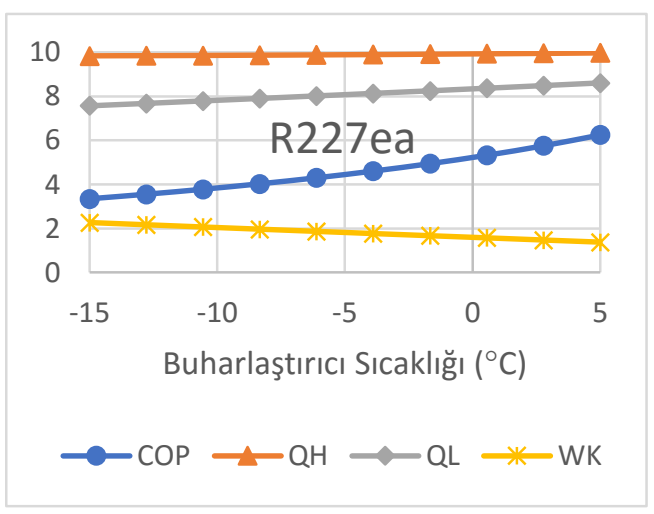

(c)

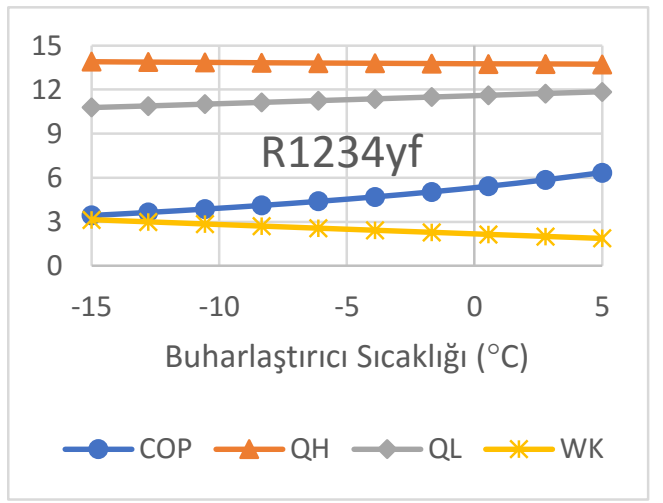

(b)

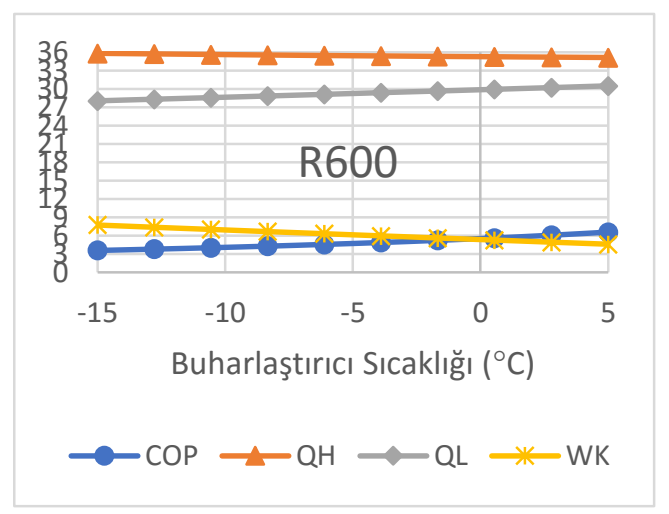

(d)

Şekil 9. Buharlaştırıcı sıcaklığının sistem performansına etkisi 


\begin{tabular}{|c|c|c|}
\hline & $\begin{array}{l}\text { BŞEÜ Fen Bilimleri Dergisi } \\
8(1), 42-55,2021\end{array}$ & $\begin{array}{r}\text { BSEU Journal of Science } \\
\text { https://doi.org/10.35193/bseufbd.826970 }\end{array}$ \\
\hline ERS & & 2458-7575 (https://dergipark.org.tr/tr/pub/bseufbd) \\
\hline
\end{tabular}

\section{Parametrik Ekserji Analizi}

Sadece enerji analizine dayanan incelemeler her zaman yeterli olmayabilmektedir. Aynı buharlaştırıcı veya yoğuşturucu, farklı koşullarda çalıştırıldığında farklı verimler elde edilebilmektedir. Bu farklılıklar ikinci yasa analizi ile belirlenebilir [21]. Enerji sistemlerinde, sistem tasarımı, optimizasyonu ve performans değerlendirmelerinde güçlü bir araç olan [15] ekserji analizi, sistemdeki kayıpları ve ne oranda olduklarını belirlemek amacı ile irdelenmiştir. Sistemdeki ekserji yıkımının artan yoğuşturucu sıcaklığı ile ve azalan buharlaştırıcı sıcaklığı ile arttığı Şekil 10'da gösterilmektedir. Her iki durumda da en yüksek kaybın R600 soğutucu akışkanı kullanılması durumunda meydana geldiği gözlemlenmiştir.

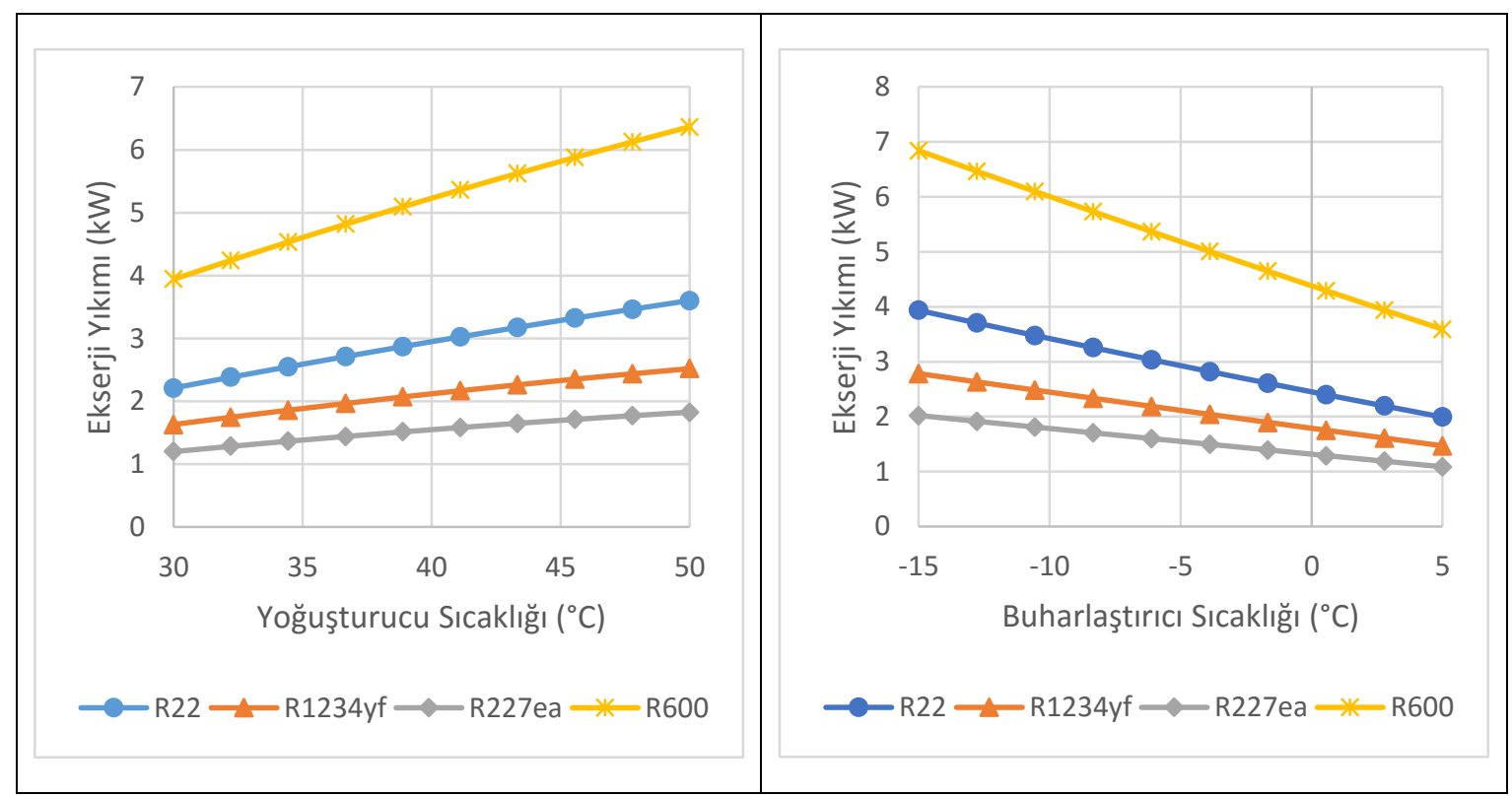

Şekil 10. Yoğuşturucu ve Buharlaştırıcı sıcaklığının ekserji yıkımına etkisi

Şekil 11'de her bir soğutucu akışkan için, değiştirilen yoğuşturucu sıcaklıklarında, sistem elemanlarında meydana gelen ekserji kayıpları ve sistemin toplam ekserji kaybı sunulmaktadır. Sistemde en yüksek ekserji yıkımının R600 soğutucu akışkanı kullanılması durumunda meydana geldiği gözlemlenmektedir. Bütün soğutucu akışkanlar için benzer bir eğilim gözlemlenmekle birlikte, yoğuşturucu sıcaklığ $37^{\circ} \mathrm{C}^{\prime}$ nin üzerine çıktı̆̆ durumlarda sistemin ekserjisini etkileyen en büyük faktörün buharlaştırıcı olduğu gözlemlenmektedir. $-3{ }^{\circ} \mathrm{C}$ buharlaştırıcı sıcaklığında, yoğuşturucu sıcaklığının artırılması ile buharlaştııcıda meydana gelen ekserji yıkımının önemli oranda arttı̆̆ 1 ve buna bağlı olarak, sistemin ekserji yıkımının da önemli oranda arttı̆̆ görülmektedir. Yoğuşturucu sıcaklığı düşük olduğu durumlarda ise, sistemin ekserji yıkımında en önemli parametre olarak yoğuşturucu olduğu gözlemlenmektedir. 


\begin{tabular}{|c|c|c|}
\hline & $\begin{array}{l}\text { BŞEÜ Fen Bilimleri Dergisi } \\
8(1), 42-55,2021\end{array}$ & $\begin{array}{r}\text { BSEU Journal of Science } \\
\text { https://doi.org/10.35193/bseufbd.826970 }\end{array}$ \\
\hline ERS & & 2458-7575 (https://dergipark.org.tr/tr/pub/bseufbd) \\
\hline
\end{tabular}

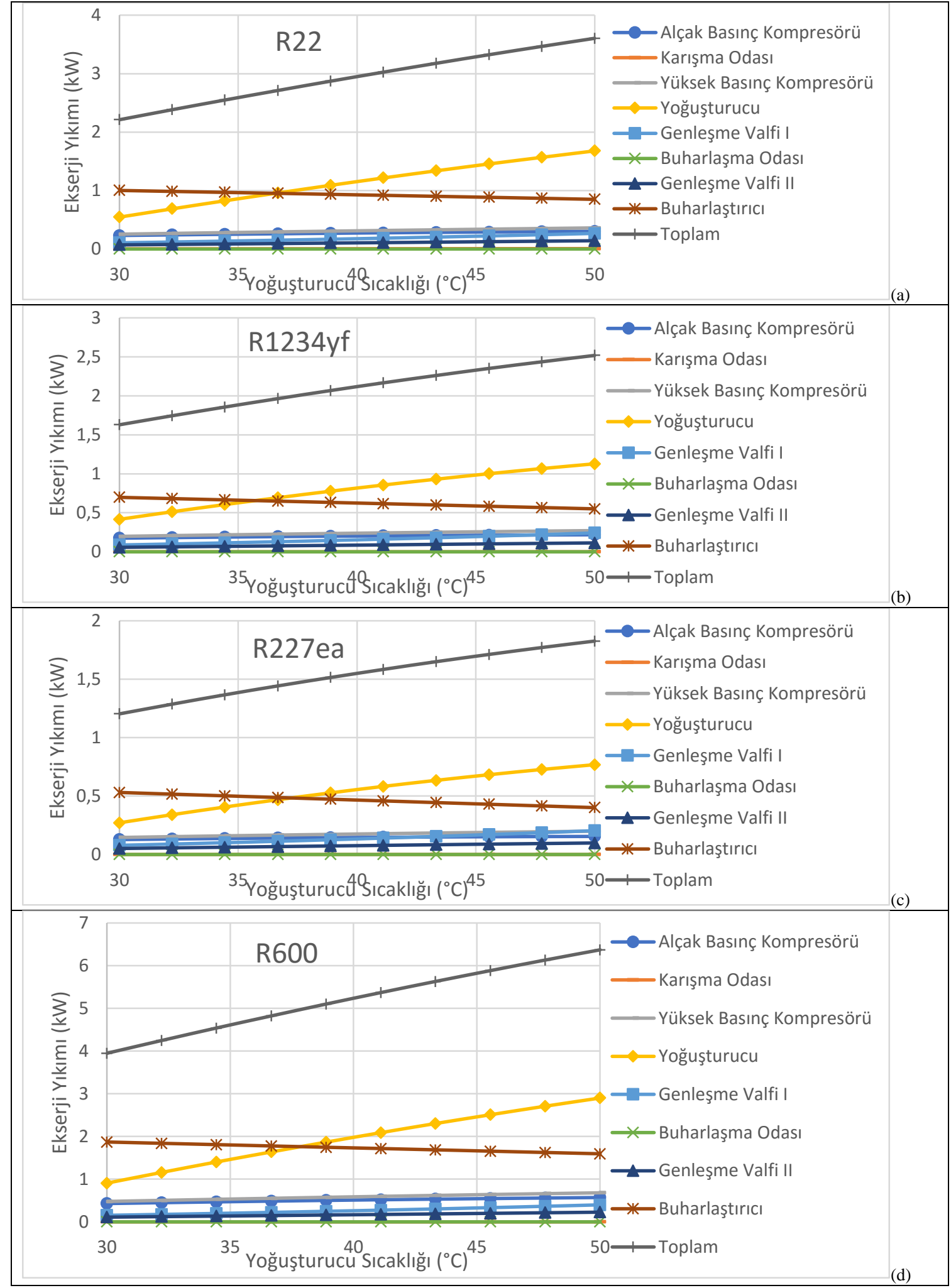

Şekil 11. Yoğuşturucu sıcaklığına bağlı olarak sistem elemanlarının ekserji yıkımları 


\begin{tabular}{|c|c|c|}
\hline & $\begin{array}{l}\text { BŞEÜ Fen Bilimleri Dergisi } \\
8(1), 42-55,2021\end{array}$ & $\begin{array}{r}\text { BSEU Journal of Science } \\
\text { https://doi.org/10.35193/bseufbd.826970 }\end{array}$ \\
\hline $\begin{array}{l}\text { BiLECIK SEYH EDEBALLL } \\
\text { ONIVERSITESI }\end{array}$ & & 2458-7575 (https://dergipark.org.tr/tr/pub/bseufbd) \\
\hline
\end{tabular}

Şekil 12'de, azalan buharlaştıııcı sıcaklığı ile sistemin ekserji yıkımının arttığı, $37{ }^{\circ} \mathrm{C}$ yoğuşturucu sıcaklı̆̆ında yapılan hesaplamalarda, buharlaştırıcı sıcaklığı belirli bir sıcaklıktan daha düşük seviyelere indikçe $\left(-3^{\circ} \mathrm{C}\right)$, sistemin ekserji değişiminde en etkili parametrenin yine buharlaştırıcı olduğu gözlemlenmektedir.

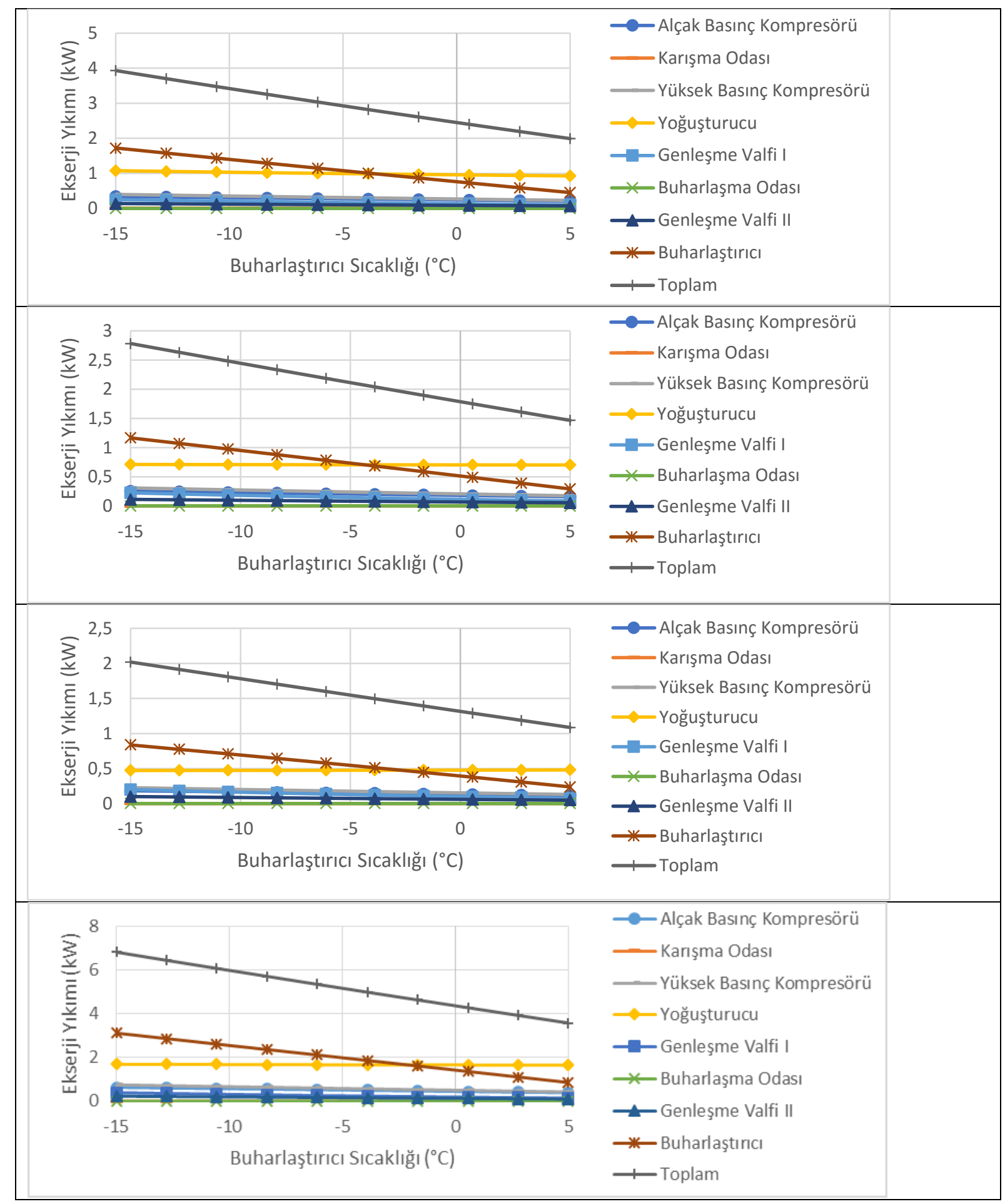

Şekil 12. Buharlaştırıcı sıcaklığına bağıı olarak sistem elemanlarının ekserji yıkımları 


\section{SONUÇLAR}

R22, R1234yf, R227ea ve R600 soğutucu akışkanlarının iki kademeli buhar sıkıştırmalı bir soğutma çevriminde; yoğuşma sıcaklığ $37{ }^{\circ} \mathrm{C}$, buharlaşma sıcaklığ $-3{ }^{\circ} \mathrm{C}, \% 82$ kompresör verimleri ve $20^{\circ} \mathrm{C}$ dış ortam sıcaklığ koşullarında kullanılmaları durumunda performans hesaplamaları yapılmıştır. Hesaplamalarda, en yüksek performans katsayısına sahip soğutucu akışkanın hem farkı yoğuşma sıcaklıklarında hem de farklı buharlaşma sicaklıklarında R600 olduğu gözlemlenmiştir. Yoğuşturucu sıcaklığı değişimlerinde R600, diğer soğutucu akışkanlardan en az \% 3 daha yüksek COP değerlerine sahipken, farklı buharlaştıııı sıcaklıklarında bu fark \% 3,5 değerinden daha fazla olmaktadır. R22 ile R1234yf değerleri birbirine çok yakın çıkmakla beraber, artan yoğuşturucu sıcaklıklarında ve azalan buharlaştırıcı sıcaklıklarında R22 kullanılması durumunda COP değerleri biraz daha fazla olmaktadır. R227ea kullanılması durumunda ise en düşük COP değerine sahip olunduğu görülmektedir. Ayrıca, soğutucu akışkan olarak R600 kullanılması durumunda, sistemdeki en yüksek basınç 348 kPa olmaktadır. Diğer soğutucu akışkanların hepsinde daha yüksek basınçlar ortaya çıkmaktadır. Yüksek basınç, kompresör gövdesinin ısınmasına neden olmakla beraber, debi kaçaklarının artmasına dolayısı ile hacimsel debinin düşmesine neden olabilmektedir.

Enerji tasarrufunu araştırmanın ve sağlamanın yolu her ne kadar kompresör işini minimuma indirmek gibi görünse de, birim soğutma için gerekli minimum gücü verdiği için performans katsayısı üzerinde değerlendirme yapmak daha cazip gelmektedir. Fakat kısıtlamalardan dolayı kullanılacak kompresör kapasitesine göre seçim yapılabileceği gibi soğutma yüküne göre de farklı akışkanların kullanılabilmesi da analizlerden çıkan bir diğer sonuçtur. R600 soğutucu akışkanı kullanıldığında daha yüksek soğutma kapasitesine ulaşıldığı gözlemlenmiştir. Sistem elemanlarında ve bütün sistemde meydana gelen kayıpları ve bu kayıpların sistem performansına etkilerini incelemek amacı ile yapılan ekserji analizi hesaplamalarında, artan yoğuşturucu sıcaklığı ve azalan buharlaştıııcı sıcaklıkları ile birlikte sistemin ekserji yıkımının da artığı gözlemlenmiştir. Parametrik olarak yapılan hesaplamalarda, $-3{ }^{\circ} \mathrm{C}$ sabit buharlaştıııcı sıcaklığında, yoğuşturucu sıcaklığının değiştirilmesi ile elde edilen sonuçlar incelendiğinde, yoğuşturucu sıcaklığının $37^{\circ} \mathrm{C}^{\prime}$ den yüksek olduğu durumlarda sistemin ekserji yıkımında en önemli faktörün buharlaştırıcı olduğu gözlemlenmektedir. Benzer olarak, $37{ }^{\circ} \mathrm{C}$ sabit yoğuşturucu sıcaklığında yapılan parametrik hesaplamalar neticesinde, buharlaştırıcı sıcaklığının $-3{ }^{\circ} \mathrm{C}$ 'den daha düşük olduğu durumlarda yine sistemin ekserji yıkımında en etkili faktörün buharlaştırıcı olduğu gözlemlenmiştir. $\mathrm{Bu}$ sonuç, literatürde yer alan, iki kademeli buhar sıkıştırmalı soğutma sistemlerinin sıcaklık fark $40{ }^{\circ} \mathrm{C}$ ve üzerinde olduğu durumlarda tercih edilmektedir bilgisi ile uyuşmaktadır. Verilen koşullarda, enerji tasarrufu açısından en uygun soğutucu akışkanın R600 olduğu sonucuna varılmıştır.

\section{KAYNAKLAR}

[1] Gupta, V. K. (1982). Optimization of multi stage refringerating systems. Doktora Tezi, Chhatrapati Sahuji Maharaj, Kanpur University, Institute of Engineering \& Technology.

[2] Öcal, P. \& Pihtıl1, K. (2014). Kademeli Soğutma Sistemlerinde Belirli Soğutucu Akişkanlar İçin İkinci Kanun Analizi. 2. Ulusal İklimlendirme Soğutma Eğitimi Sempozyumu ve Sergisi, 23-25 Ekim 2014, Balıkesir.

[3] Torrella, E., Llopis, R. \& Cabello, R. (2009). Experimental evaluation of the inter-stage conditions of a twostage refrigeration cycle using a compound compressor, Int. J. Refrig., 32 (2), 307-315.

[4] Çengel, Y. A. \& Boles, M.A. (2002). Thermodynamics: An Engineering Approach, $4^{\text {th }}$ ed. McGraw Hill, New York.

[5] Ouadha, A., En-nacer, M., Adjlout, L. \& Imine, O. (2005). Exergy analysis of a two-stage refrigeration cycle using two natural substitutes of HCFC22, Int. J. Exergy, 2 (1),14-30.

[6] Baakeem, S. S., Orfi, J. \& Alabdulkarem, A. (2018). Optimization of a multistage vapor-compression refrigeration system for various refrigerants, Appl. Therm. Eng., 136, 84-96.

[7] Liu, S., Lu, F., Dia, B., Nian, V., Li, H., Qi, H. \& Li, J. (2019). Performance analysis of two-stage compression transcritical CO2 refrigeration system with R290 mechanical subcooling unit, Energy, 189, 116-143.

[8] Voloshchuk. V., Thermodynamic Calculations of Two-Stage Vapor Compression Refrigeration Cycle with Flash Chamber and Separate Vapor.

[9] Xuan, X. C. (2003) Optimum staging of multistage exo-reversible refrigeration systems, Cryogenics, 43 (2), $117-124$.

[10] Nikolaidis C. \& Probert, D. (1998). Exergy-method analysis of a two-stage vapour-compression refrigeration-plants performance, Appl. Energy, 60 (4), 241-256. 
[11] Prasad, M. (1981). Optimum interstage pressure for two stage refrigeration system, ASHRAE J., 23, 58-60.

[12] Zubair, S. M. \& Khan, S. H. (1995). On Optimum Interstage Pressure for Two-Stage and MechanicalSubcooling Vapor-Compression Refrigeration Cycles, J. Sol. Energy Eng., 117 (1), 64-66.

[13] Zubair, S., Yaqub, M. \& Khan, S. (1996). Second-law-based thermodynamic analysis of two-stage and mechanical-subcooling refrigeration cycles, Int. J. Refrig. Int. Du Froid - INT J Refrig, 19, 506-516.

[14] Ratts, E. B. \& Steven Brown, J. (2000). A generalized analysis for cascading single fluid vapor compression refrigeration cycles using an entropy generation minimization method, Int. J. Refrig., 23(5), 353-365.

[15] Yumrutaş, R., Kunduz, M. \& Kanoğlu, M. (2002). Exergy analysis of vapor compression refrigeration systems, Exergy, An Int. J., 2 (4), 266-272.

[16] Chopra, K., Sahni, V. \& Mishra, R. S. (2015). Energy, exergy and sustainability analysis of two-stage vapour compression refrigeration system, J. Therm. Eng., 1 (4), 440-445.

[17] Anand, S., Gupta, A. \& Tyagi, S. K. (2013). Simulation studies of refrigeration cycles: A review, Renew. Sustain. Energy Rev., 17, 260-277.

[18] Kabul, A., Kizilkan, Ö. \& Yakut, A. K. (2008). Performance and exergetic analysis of vapor compression refrigeration system with an internal heat exchanger using a hydrocarbon, isobutane (R600a), Int. J. Energy Res., 32 (9), 824-836.

[19] Kalaiselvam, S. \& Saravanan, R. (2009). Exergy analysis of scroll compressors working with r22 , r407c , and r417a as refrigerant for hvac system, Thermal Science, 13(1), 175-184.

[20] Ahamed, J. U., Rahman, S. \& Masjuki, H. H. (2010). Thermodynamic Performance Analysis of R-600 and R-600a as Refrigerant, Eng. e-Transaction, 5 (1), 11-18.

[21] Ahamed, J. U., Saidur, R. \& Masjuki, H. H. (2011). A review on exergy analysis of vapor compression refrigeration system, Renew. Sustain. Energy Rev., 15(3), 1593-1600.

[22] Vincent, C. E. \& Heun, M. K. (2006). Thermoeconomic Analysis \& Design of Domestic Refrigeration Systems. 